\title{
Faktor Determinan Perilaku Konservasi Energi dalam Skala Rumah Tangga dan Sektor Transportasi pada Konsumen Produk Elektronik Ramah Lingkungan dan BBM Non-Subsidi
}

\section{Determinants of Conservation Behaviour of Green Electronic Products and Non-Subsidized Fuel Consumers}

\author{
Rizqy Amelia Zein', E Ilham Nur Alfian² \\ Departemen Psikologi Kepribadian dan Sosial \\ Fakultas Psikologi Universitas Airlangga
}

\begin{abstract}
Excessive energy consumption is the main cause of high emissions in our atmosphere, so that energy conservation remains a vital issue in combatting climate change. This research aimed to investigate determinant factors that supported conservation behaviour of green electronic products and non-subsidised petrol consumer. The research was conducted using survey design by employing a combination of paper-based and online questionnaire. This research uses the combination techniques of webpage-based self-completion questionnaire and paper-based selfcompletion question-naire. Involving 143 respondents, this research came into conclusion that key determinant factor which influenced energy conservation behaviour in household sector is external motivation or reducing household energy costs, so that it can be categorized as rational decision. Meanwhile in transportation sector, intrinsic motivation and pro-environmental values were important determinant factors that enticing energy consumption behaviour. Therefore, energy conservation behaviour in transportation sector is determined by internalfactors, so that it is mentioned as an idealistic decision.
\end{abstract}

Keywords: energy consumption behaviour; green-electronic products; household; transportation

Abstrak. Konsumsi energi yang berlebihan merupakan penyebab utama menumpuknya emisi karbon di atmosfir, sehingga isu mengenai konservasi energi menjadi isu yang penting untuk mengatasi perubahan iklim. Tujuan penelitian ini untuk mengidentifikasi faktor determinan yang berpengaruh pada perilaku konservasi energi pada pengguna produk elektronik ramah lingkungan dan bahan bakar non-subsidi. Penelitian ini menggunakan desain penelitian survei dan menggunakan kombinasi kuesioner cetak dan daring yang diisi oleh 143 responden. Penulis menggunakan kombinasi teknik webpage-based self-completion questionnaire dengan paper-based selfcompletion question-naire. Hasil dari penelitian ini menunjukkan bahwa faktor determinan perilaku konservasi energi pada skala rumah tangga yang utama adalah motivasi eksternal, yaitu penghematan biaya belanja energi, sehingga dapat digolongkan sebagai keputusan rasional. Namun pada sektor transportasi, faktor determinan yang utama adalah motivasi intrinsik dan nilai prolingkungan. Artinya, perilaku konservasi dalam sektor transportasi ditimbulkan oleh faktor-faktor internal yang idealis, sehingga dapat dikategorikan sebagai keputusan idealis.

Kata kunci: perilaku konservasi energi; produk ramah lingkungan; rumah tangga; transportasi

Perubahan iklim dan pemanasan global bukan lagi persoalan yang dihadapi oleh satu-dua negara, karena dampaknya bisa dirasakan oleh siapa saja dan menembus batas negara serta kelas sosial. Selain itu, risiko pemanasan global di masa depan diperkirakan semakin memburuk dan akumulatif, sehingga efek kerusakannya

\footnotetext{
${ }^{1}$ Korespondensi mengenai artikel ini dapat melalui: amelia.zein@psikologi.unair.ac.id
} 
yang terburuk sangat mungkin dirasakan oleh generasi mendatang (APA Task Force, 2009; Demeritt, 2006).

Laporan yang dirilis oleh UN Intergovernmental Panel on Climate Change (IPCG) pada tahun 2014 menegaskan bahwa dampak pemanasan global, seperti cuaca yang makin tidak menentu dan efekefek kerusakan lingkungan lainnya, telah dirasakan dalam satu dekade terakhir dan akan semakin buruk dalam beberapa tahun ke depan (Sugiyono, 2012). Lebih lanjut, IPCG juga menegaskan bahwa efek pemanasan global dipredisikan lebih merusak dibandingkan dengan yang awalnya diprediksikan pada tahun 2007 (Connor, 2014). Selain anomali cuaca dan kerusakan ekologis lainnya, efek negatif yang riil dari pemanasan global diantaranya adalah rusaknya ketahanan pangan, suplai air bersih, kesehatan manusia, pertumbuhan ekonomi dan meningkatnya angka kemiskinan (Connor, 2014; Corner et al., 2011; Mayer, 2014).

Pemanasan global merupakan implikasi dari akumulasi risiko lingkungan yang penyebab utamanya adalah tingginya emisi karbon (greenhouse effect). Padahal, kombinasi antara overpopulasi dengan meledaknya konsumsi energi merupakan faktor penyumbang utama meningkatnya level emisi karbon (Connor, 2014; Mayer, 2014). Oleh karena itu, studi-studi psikologi yang berkaitan dengan pemanasan global banyak membahas mengenai perilaku konsumsi dan konservasi energi serta faktor-faktor determinannya (APA Task Force, 2009).

Konsumsi energi dalam level rumah tangga memang tidak terlalu besar bila dibandingkan dengan konsumsi energi di sektor komersial atau industri. Misalnya pada tahun 2030, permintaan suplai energi dalam sektor rumah tangga diprediksikan bertumbuh sampai pada angka 352 juta
SBM (setara barel minyak), masih jauh di bawah sektor industri yang mencapai 1.065 juta SBM pada tahun yang sama (Pusat Teknologi Pengembangan Sumberdaya Energi, 2014; Sekretariat Panitia Teknis Sumber Energi, 2006; Sugiyono, 2012). Meskipun begitu, pengelolaan konservasi energi dalam sektor rumah bukan berarti bisa dikesampingkan. Program konservasi energi dalam skala rumah tangga seharusnya juga disertai dengan kampanye persuasif yang mendorong masyarakat untuk memilih produk-produk yang dihasilkan dari teknologi yang ramah lingkungan (Costanzo, Archer, Aronson, \& Pettigrew, 1986; Muryanto, 2014). Dengan memilih produk yang dihasilkan dari teknologi yang ramah lingkungan, sektor industri akan terdorong untuk melakukan konservasi energi dalam skala yang lebih besar (Muryanto, 2014). Selain itu, proporsi terbesar dampak kerusakan lingkungan selalu berkaitan dengan konsumsi energi di sektor transportasi dan sektor rumah tangga (Peattie, 2010).

Bahkan dalam skala rumah tangga, Indonesia menempati peringkat pertama negara yang paling boros energi di ASEAN dengan tingkat ketergantungan yang tinggi terhadap pendingin udara (air conditioner). Padahal pendingin udara dan lemari es merupakan peralatan rumah tangga yang paling boros energi dan mengeluarkan gas emisi yang berbahaya bagi ekosistem (Nossar, 2014).

Sektor lainnya yang mendesak untuk dilakukan penghematan adalah sektor transportasi. Sugiyono (2012) mencatat bahwa pertumbuhan proyeksi kebutuhan energi diperkirakan akan meningkat ratarata $6.9 \%$ pertahun, sehingga diperkirakan pada tahun 2030 permintaan energi dalam sektor transportasi mencapai 963 juta setara barrel minyak (SBM). Konsumsi energi juga tercatat masih cukup tinggi, yaitu 
mengalami kenaikan rata-rata $6.2 \%$ pertahun dan masih menempatkan bahan bakar fosil sebagai jenis bahan bakar yang paling banyak dikonsumsi apabila dibandingkan dengan jenis bahan bakar lainnya yang lebih sustainable. Moda transportasi yang diklaim paling banyak memakan bahan bakar adalah Angkutan Jalan Raya, yaitu dengan total konsumsi sekitar Rp20-30 triliun pertahun, serta menempatkan sepeda motor sebagai moda transportasi dengan jumlah terbanyak (78 juta unit pada tahun 2010) (Sugiyono, 2012). Oleh karena itu, pemilihan jenis bahan bakar yang lebih hemat energi dan ramah lingkungan merupakan titik krusial yang menjelaskan perilaku konservasi energi dalam sektor transportasi (Mayer, 2014; Sugiyono, 2012).

Berbagai penelitian telah membuktikan bahwa target perilaku yang paling efektif dalam menghemat energi paling besar bukanlah perilaku konservasi energi yang sifatnya individual seperti carpooling dan sebagainya, namun pada pemilihan teknologi yang ramah lingkungan, contohnya menggunakan pendingin ruangan dan lemari es yang berteknologi inverter (Harland, Staats, \& Wilke, 2007; Stratospheric Protection Division, 2014). Memberikan penguatan (reinforcement) pada pemilihan teknologi yang ramah lingkungan, meskipun bukan perilaku yang rutin dilakukan setiap hari, ternyata memiliki dampak penghematan energi yang lebih besar (Brandon \& Lewis, 1999).

Costanzo, et al. (1986) menjelaskan bahwa perilaku konservasi energi dapat dijelaskan oleh dua dimensi, yaitu dimensi psikologis dan dimensi positional. Model yang dikemukakan oleh Costanzo, et al. (1986) ini merupakan elaborasi atas elemen sikap dan rational models serta dikombinasikan dengan faktor-faktor determinan tambahan yang memengaruhi perilaku konservasi energi. Dimensi psikologis ini meliputi nilai-nilai yang dianut oleh individu, yang diwakili oleh konstruk norm activation model (NAM) dan belief serta sikap atas isu lingkungan yang diwakili oleh konstruk new environmental paradigm (NEP). Selanjutnya, dimensi positional ini meliputi pendapatan bersih (disposable income), status kepemilikan rumah (home ownership), kemampuan melakukan perbaikan kecil pada kerusakan rumah (home repair skills) dan kepemilikan perkakas rumah tangga yang hi-tech (homeownership technology).

Norm Activation Theory (NAT) pada dasarnya mencakup kondisi di mana seseorang menyadari bahwa; pertama, perilakunya berkontribusi pada persoalan lingkungan (problem awareness). Problem awareness ini juga mencakup situasi dimana individu menyadari bahwa dirinya bertanggung jawab atas persoalan lingkungan serta tidak menyalahkan pihak lainnya (industri atau pemerintah) atas persoalan lingkungan yang terjadi (ascription of responsibility). Selain itu, individu dengan nilai personal yang cenderung pro-lingkungan merasa yakin bahwa perilakunya berkontribusi positif terhadap perbaikan kondisi ekosistem (outcome efficacy). Yang terakhir, NAT juga mencakup penjelasan bahwa individu harus merasa yakin bahwa dirinya sanggup untuk memberikan kontribusi terhadap aksi-aksi penyelamatan ekosistem (self-efficacy). Dimensi yang terakhir memiliki kemiripan konsep dengan perceived behavioural control (PBC) pada model theory of planned behavior, meskipun PBC arahnya lebih kepada keyakinan individu atas kontrol yang ia miliki untuk melakukan suatu perilaku (Harland, et al., 2007; Steg \& de Groot, 2010; Steg, Van den Berg, \& De Groot, 2013). 
NAT cenderung lazim digunakan dalam menjelaskan perilaku prolingkungan; seperti, perilaku konservasi energi, kemauan untuk membayar biaya perlindungan lingkungan (environmental protection), dan sebagainya (Han, 2014; van der Werff \& Steg, 2015). Meskipun begitu, studi-studi ini juga melibatkan variabel situasional atau variabel positional, seperti tingkat pendapatan, tingkat pendidikan, status kepemilikan rumah dan sebagainya (Harland, et al., 2007; Steg, et al., 2013).

\section{Selain NAT, New Environmental} Paradigm (NEP) merupakan model mental yang sering digunakan dalam menjelaskan perilaku pro-environmental dan perilaku konservasi. NEP juga seringkali digunakan untuk menjelaskan public attitude mengenai kualitas lingkungan dan isu-isu tentang penurunan kualitas ekologi (Dunlap, Liere, Mertig, \& Jones, 2000). Dalam artikelnya, Schultz (2005) menjelaskan bahwa NEP dapat digunakan untuk mengukur sikap seseorang (terutama menekankan pada komponen evaluatifnya) atas perubahan iklim yang terjadi secara perlahan namun dengan daya destruktif yang luar biasa.

Dunlap (2008) memfokuskan NEP sebagai konseptualisasi atas belief seseorang mengenai manusia sebagai pengganggu stabilitas alam, adanya batas/limit dalam pertumbuhan peradaban manusia dan hak manusia sebagai ras yang mengatur sumber daya alam. Oleh karena itu, skala NEP seringkali digunakan dalam banyak penelitian sebelumnya untuk mengungkap sikap dan belief seseorang mengenai perubahan iklim (Kaiser, Wölfing, \& Fuhrer, 1996; Schultz \& Zelezny, 1999). NEP dianggap unggul dalam mengungkap dimensi sikap dan belief seseorang mengenai perubahan iklim karena dianggap mampu menyentuh primitive belief mengenai hukum alam dan relasi antara manusia dengan alam, sedangkan primitive belief ini dipercayai berasal dari inti terdalam (inner core) dari sistem belief seseorang dan merepresentasikan realitas fisik, realitas sosial dan sifat dasar self (Dunlap, et al., 2000). Bila dibandingkan dengan NAT, NEP dapat menyentuh aspek belief atas perilaku (aspek sikap), sedangkan NAT lebih berfokus pada nilai (value) yang dianut oleh seseorang mengenai relasi antara manusia dengan alam semesta (Vining \& Ebreo, 2002).

Dimensi positional yang dianggap memiliki efek langsung terhadap perilaku konservasi energi, menurut penelitian yang dilakukan oleh Costanzo, et al. (1986), Gifford (1997) dan Brandon dan Lewis (1999), adalah status kepemilikan rumah (home ownership status), status sosioekonomi (socioeconomic status), memiliki wewenang untuk mengambil keputusan pemilihan produk elektronik (ownership of home technologies), ada atau tidaknya anggota keluarga yang memiliki keterampilan melakukan perbaikan-perbaikan kecil pada rumah (home repair skill).

Produk elektronik yang ramah lingkungan seperti pendingin ruangan yang menggunakan teknologi inverter misalnya, membutuhkan investasi dana yang tidak sedikit karena harga produk dan biaya perawatannya cenderung lebih mahal dibandingkan dengan produk konvensional. Oleh karena itu, status sosioekonomi seperti tingkat pendapatan, pendidikan dan usia, tentunya akan berpengaruh pada keputusan membeli produk ramah lingkungan (Costanzo, et al., 1986; Gifford, 1997).

Penyewa rumah biasanya memiliki tingkat pendapatan yang lebih rendah dari pemilik rumah dan tidak terdorong untuk membeli produk-produk high-end, sehingga status kepemilikan rumah dan memiliki wewenang untuk mengambil keputusan 
pemilihan produk elektronik menjadi aspek yang penting dalam perilaku konservasi energi (Costanzo et al., 1986). Kehadiran seseorang yang memahami teknologi dan mampu melakukan perbaikan kecil pada rumah menjadi aspek yang juga penting. Kehadiran seorang handyperson, tidak hanya mereduksi biaya pemasangan dan perawatan, melainkan juga mendorong terjadinya keputusan membeli produk yang ramah lingkungan dan hemat energi (Brandon \& Lewis, 1999; Costanzo et al., 1986). Seorang handyman biasanya memiliki pengetahuan yang lebih baik mengenai spesifikasi, fungsi dan kekurangan atau kelebihan suatu alat elektronik daripada orang awam, sehingga cenderung memutuskan untuk memilih produk ramah lingkungan, karena mengetahui kelebihan dan manfaatnya.

Dengan memahami faktor-faktor determinan perilaku konservasi energi, penelitian ini berupaya mendapatkan profil pengguna produk ramah lingkungan. Selain itu, penelitian ini akan berupaya mengidentifikasi faktor-faktor yang paling signifikan dalam memengaruhi perilaku konservasi energi individu dalam skala rumah tangga. Harapannya, kampanye konservasi energi serta usaha intervensi sosial lainnya yang berupaya untuk mempromosikan perilaku konservasi energi, dapat didesain dan dilaksanakan secara optimal dengan mempertimbangkan faktor determinan perilaku konservasi energi.

Kami mengajukan hipotesis bahwa individu yang memiliki sikap (NEP), nilai pro-lingkungan (NAT) dan motivasi intrinsik yang intens, tinggal serumah dengan seorang handyman, serta memiliki disposisi motivasi ekstrinsik yang rendah, akan cenderung melakukan perilaku konservasi energi, yaitu membeli produk inverter (AC dan/atau kulkas) dan/atau BBM non-subsidi.

\section{Metode}

Penelitian ini menggunakan desain penelitian survei. Alasannya, sebagian besar penelitian-penelitian sebelumnya mengenai perilaku konservasi energi menggunakan desain penelitian yang serupa (Attari, DeKay, Davidson, \& de Bruin, 2010; Costanzo et al., 1986; Kantola, Syme, \& Campbell, 1984; Raaij \& Verhallen, 1983; Stern, 1992). Selain itu, desain penelitian survei merupakan desain yang paling cocok dengan konteks penelitian yang berupaya untuk mengidentifikasi faktor-faktor determinan perilaku konservasi energi. Dengan menggunakan desain survei sosial, penulis dapat mengidentifikasi dimensi psikologis dan positional yang berperan sebagai determinan perilaku konservasi energi (Bryman, 2012; Corbetta, 2003; De Vaus, 2002).

\section{Variabel penelitian}

Norm Activation Theory (NAT). Norm activation theory terdiri dari tiga dimensi yaitu; problem awareness, yaitu ketika seseorang menyadari bahwa perilakunya juga berkontribusi terhadap kerusakan lingkungan; ascription of responsibility, yaitu ketika individu merasa bertanggung jawab atas kerusakan lingkungan yang terjadi; outcome efficacy, yaitu individu merasa yakin bahwa perilakunya dapat berdampak positif terhadap perbaikan lingkungan hidup; dan self-efficacy, yaitu ketika seseorang merasa yakin bahwa dirinya memiliki kapasitas untuk memberikan kontribusi terhadap perilaku konservasi energi (Han, 2014; van der Werff \& Steg, 2015). Skala NAT merupakan skala likert yang terdiri dari 12 aitem yang 
terdiri dari 5 pilihan jawaban (sangat tidak setuju - sangat setuju), yang merupakan skala yang diadaptasi dari penelitian (De Groot dan Steg (2009). Reliabilitas skala dihitung dengan menggunakan Cronbach's alpha dan menghasilkan koefisien sebesar 0.825 , yang menandakan bahwa skala NAT memiliki reliabilitas yang baik.

New Ecological Paradigm (NEP). Belief dan sikap seseorang mengenai relasi manusia dengan lingkungan diwakili oleh konstruk new environmental paradigm (NEP), yang mencakup tiga dimensi, yaitu belief seseorang mengenai manusia sebagai pengganggu stabilitas alam, adanya batas/limit dalam pertumbuhan peradaban manusia dan hak manusia sebagai ras yang mengatur sumber daya alam (Dunlap, 2008). Skala NEP merupakan skala likert yang terdiri dari 13 aitem dengan 5 pilihan jawaban (sangat tidak setuju - sangat setuju). Reliabilitas skala dihitung dengan menggunakan Cronbach's alpha dan menghasilkan koefisien sebesar 0.5, yang menandakan bahwa skala NAT memiliki reliabilitas yang cenderung moderate.

Motivasi perilaku konservasi. Motivasi seseorang dalam melakukan konservasi energi, yang terdiri dari 3 dimensi, yakni motivasi intrinsik, ekstrinsik dan non-materialism (Young, 1985, 1996). Skala motivasi merupakan skala likert yang terdiri dari 10 aitem dengan 5 pilihan jawaban (sangat tidak setuju - sangat setuju). Skala motivasi intrinsik berisi 4 aitem yang menanyakan apakah responden cenderung mengutamakan motif kepuasan personal yang nonmaterial ketika memilih produk yang ramah lingkungan. Skala motivasi ekstrinsik berisi 2 aitem yang mengukur kecenderungan responden mencari keuntungan finansial ketika memilih produk yang ramah lingkungan.
Skala non-materialism ditujukan untuk mengungkap kecenderungan responden mengadopsi pendekatan non-materialistik. Skala ini mencakup motif responden untuk menjalani hidup yang sederhana, kemauan untuk mengorbankan kesenangan yang hanya bisa dinikmati jangka pendek untuk keuntungan yang mungkin diraih di masa depan, serta kemauan untuk mengadopsi pendekatan yang non-oportunistik, sehingga individu menghindari kecenderungan untuk mencari keuntungan pribadi di setiap kesempatan (Young, 1996). Penelitian sebelumnya mengungkapkan bahwa skala non-materialism memiliki korelasi yang amat rendah dengan skala motivasi instrinsik dan ekstrinsik, sehingga mengindikasikan independensi variabel ini (Young, 1985). Setelah dilakukan pengujian reliabilitas dengan teknik Cronbach's alpha, maka reliabilitas skala motivasi ekstrinsik, intrinsik dan non-materialism masingmasing adalah $0.63,0.871$, dan 0.666 , yang menunjukkan reliabilitas yang cenderung moderate dan tinggi.

Dimensi positional. Dimensi positional terdiri dari pertanyaan mengenai; (a) status sosioekonomi responden, yaitu mencakup tingkat pendapatan personal, tingkat pendidikan dan usia; (b) status kepemilikan rumah; dan (c) memiliki/ tidak memiliki wewenang untuk mengambil keputusan pemilihan produk elektronik; dan (d) ada/tidaknya anggota keluarga yang memiliki keterampilan melakukan perbaikan-perbaikan kecil pada rumah (handyman).

\section{Responden}

Sebanyak 143 responden terlibat dalam penelitian ini dengan kriteria; (a) berusia minimal 18 tahun dan (b) menggunakan satu atau lebih produk elektronik ramah lingkungan (pendingin ruangan inverter, 
lemari es inverter dan/atau BBM nonsubsidi - semua jenis bahan bakar yang dijual di pasaran, kecuali Premium dan Solar bersubsidi). Asumsinya, individu yang berusia 18 tahun ke atas dipandang sudah mampu mengambil keputusan membeli/mengkonsumsi produk tertentu.

\section{Teknik penggalian dan analisis data}

Penulis menggunakan kombinasi teknik webpage-based self-completion questionnaire dengan paper-based self-completion questionnaire, dimana pada pendekatan yang pertama kuesioner akan diadministrasikan secara daring. Alasannya, metode ini sangat murah, praktis, mampu menjangkau partisipan yang berdomisili di daerah yang tidak mampu dijangkau oleh peneliti dan sangat mudah dijangkau oleh partisipan. Partisipan penelitian bisa mengisi kuesioner di setiap waktu dan tempat dengan akses internet. Selain itu, dengan menggunakan teknik tersebut, data yang diperoleh dari pengambilan data akan segera direkam dan disimpan secara aman (De Vaus, 2002; Eysenbach \& Wyatt, 2002; Sue \& Ritter, 2006). Teknik yang kedua dipakai untuk melengkapi kekurangan teknik pertama, yaitu mampu menjangkau responden yang belum mampu mengakses kuesioner daring.

Penulis juga menawarkan undian berhadiah kepada partisipan survei, baik pada partisipan yang mengisi kuesioner cetak, maupun kuesioner daring, sebagai strategi untuk meningkatkan tingkat respons (response rate) (Bryman, 2012; De Vaus, 2002). Untuk menentukan variabel prediktor yang substansial menjelaskan keputusan pemakaian produk ramah lingkungan, penulis menggunakan teknik analisis regresi logistik dengan bantuan IBM SPSS 20. Parameter robustness variabel prediktor dalam regresi logistik direpresentasikan oleh adjusted odd ratio, 95\% confidence interval dan nilai $p$, secara berurutan.

\section{Hasil}

Berdasarkan Tabel 1 yang menjabarkan hasil analisis regresi logistik dengan penggunaan produk inverter (AC dan/ atau Kulkas) sebagai variabel dependen menunjukkan model fit, artinya model dapat menjelaskan variabel dependen dengan baik. Responden yang menggunakan salah satu atau kedua produk inverter (AC dan kulkas) diberi kode 1, sedangkan responden yang tidak menggunakan produk inverter sama sekali diberi kode 0. Analisis regresi logistik menggunakan listwise deletion, sehingga tidak menyertakan responden yang datanya missing dalam modelnya. Analisis ini mencakup 129 partisipan yang datanya lengkap dari total 143 partisipan yang terkumpul.

Pseudo-R (Nagelkerke $\mathrm{R}^{2}$ ) menunjukkan nilai 0.123 , artinya $12.3 \%$ varian skor prediktor dapat menjelaskan varian skor variabel dependen. Prediktor yang teridentifikasi signifikan secara statistik adalah motivasi ekstrinsik $(1.185,1.019$ $1.378,0.027)$ dan adanya handyman $(0.344$, 0.140-0.842, 0.020). Individu dengan motivasi ekstrinsik yang tinggi akan berpeluang lebih besar untuk memilih menggunakan produk inverter, namun kehadiran handyman yang tinggal bersama dengan responden, justru menurunkan peluang responden akan memilih produk kulkas dan AC inverter. Proporsi responden dengan handyman yang menggunakan produk inverter (59.5\%) jauh lebih tinggi daripada responden yang tidak tinggal serumah dengan seorang handyman (22.2\%). 
Tabel 1.

Hasil regresi logistik penggunaan produk inverter (AC dan/atau Kulkas) (N=129)

\begin{tabular}{|c|c|c|c|c|c|c|c|c|}
\hline \multirow[t]{2}{*}{ Variabel Determinan } & \multicolumn{2}{|c|}{$\begin{array}{c}\text { Menggunakan } \\
\text { Inverter }\end{array}$} & \multicolumn{2}{|c|}{$\begin{array}{l}\text { Tidak Menggu- } \\
\text { nakan Inverter }\end{array}$} & \multirow[t]{2}{*}{ Nilai $p$} & \multirow[t]{2}{*}{$\mathrm{aOR}$} & \multicolumn{2}{|c|}{$95 \% \mathrm{CI}$} \\
\hline & $\mathrm{n}$ & $\%$ & $\mathrm{n}$ & $\%$ & & & Lower & Upper \\
\hline NAT & & & & & 0.604 & 0.989 & 0.946 & 1.033 \\
\hline NEP & & & & & 0.937 & 0.998 & 0.952 & 1.046 \\
\hline Motivasi Intrinsik & & & & & 0.232 & 1.056 & 0.966 & 1.154 \\
\hline Motivasi Ekstrinsik & & & & & $0.027^{*}$ & 1.185 & 1.019 & 1.378 \\
\hline Non-materialism & & & & & 0.153 & 0.920 & 0.821 & 1.031 \\
\hline \multicolumn{9}{|l|}{ Adanya handyman } \\
\hline Tidak Ada & 35 & 77.8 & 10 & 22.2 & & 1.000 & & \\
\hline Ada & 34 & 40.5 & 50 & 59.5 & $0.020^{*}$ & 0.344 & 0.140 & 0.842 \\
\hline Constant & & & & & 0.617 & 4.964 & & \\
\hline
\end{tabular}

aOR $=$ adjusted odd ratio, ${ }^{*} \mathrm{p}<0.05$, Nagelkerke $\mathrm{R}^{2}=0.123$, Nilai $\mathrm{p}$ Omnibus Tests of Model Coefficient $<0.05$

Tabel 2 merupakan hasil regresi logistik dengan penggunaan BBM nonsubsidi sebagai variabel dependen. Responden yang menggunakan BBM nonsubsidi diberi kode 1, sedangkan yang tidak menggunakan BBM non-subsidi diberi kode 0. Hasil Omnibus Tests menunjukkan bahwa model menunjukkan model fit, artinya prediktor dapat bekerja dengan baik dalam menjelaskan variabel dependen. Analisis regresi logistik menggunakan listwise deletion, sehingga tidak menyertakan responden yang datanya missing dalam modelnya. Analisis ini mencakup 129 partisipan yang datanya lengkap dari total 143 partisipan yang terkumpul.
Pseudo-R (Nagelkerke $\mathrm{R}^{2}$ ) menunjukkan nilai 0.251 , artinya $25.1 \%$ varian skor prediktor dapat menjelaskan varian skor variabel dependen. Prediktor yang teridentifikasi signifikan secara statistik adalah NAT $(1.049,1.005-1.096,0.029)$ dan motivasi ekstrinsik (0.716, 0.607-0.845, $0.000)$. Semakin intens nilai pro-lingkungan (NAT) individu, maka lebih besar peluangnya untuk memilih menggunakan BBM non-subsidi. Namun menariknya, BBM non-subsidi bukan pilihan responden dengan motivasi eksternal yang tinggi, karena apabila tendensi mencari keuntungan material semakin intens, justru responden akan cenderung menghindari memilih BBM non-subsidi.

Tabel 2.

Hasil regresi logistik penggunaan BBM Non-Subsidi ( $N=129)$

\begin{tabular}{lcccc}
\hline \multirow{2}{*}{ Variabel Determinan } & \multirow{2}{*}{ Nilai $\mathrm{p}$} & \multirow{2}{*}{ aOR } & \multicolumn{2}{c}{$95 \% \mathrm{CI}$} \\
\cline { 4 - 5 } & & 1.049 & 1.005 & Lower \\
\hline NAT & $.029^{*}$ & .982 & .937 & 1.096 \\
NEP & .435 & 1.008 & .925 & 1.028 \\
Motivasi Intrinsik & .864 & .716 & .607 & .097 \\
Motivasi Ekstrinsik & $.000^{*}$ & .096 & .980 & 1.225 \\
Non-materialism & .108 & .074 & & \\
Constant & .420 & .074 & \\
\hline
\end{tabular}

aOR $=$ adjusted odd ratio, ${ }^{*} \mathrm{p}<0.05$, Nagelkerke $\mathrm{R}^{2}=0.251$, Nilai $\mathrm{p}$

Omnibus Tests of Model Coefficient $<0.05$ 
Dari Tabel 3 dapat disimpulkan bahwa sebagian besar responden yang mengaku menggunakan BBM non-subsidi menunjukkan disposisi negatif terhadap motivasi ekstrinsik, artinya ketika memilih BBM non-subsidi, para responden cenderung mengabaikan motivasi eksternal. Bila membandingkan temuan penelitian yang disajikan di Tabel 2 dengan Tabel 3, terlihat bahwa responden yang menjadi konsumen BBM non-subsidi memiliki NAT yang cenderung lebih tinggi. Oleh karena itu, dapat disimpulkan bahwa konsumen BBM non-subsidi merupakan konsumen 'idealis' karena motivasi mencari keuntungan finansial, bukanlah faktor yang krusial dalam menjelaskan perilaku konservasi energi dalam sektor transportasi.

Tabel 4 menunjukkan hasil regresi logistik dengan penggunaan produk inverter (AC dan/atau kulkas) dan BBM non-subsidi. Responden yang menggunakan salah satu atau kedua produk inverter (AC dan kulkas) sekaligus memilih menggunakan BBM non-subsidi diberi kode 1. Responden yang hanya menggunakan produk inverter saja, menggunakan BBM non-subsidi saja atau tidak menggunakan produk inverter maupun BBM non-subsidi sama sekali, diberi kode 0 . Responden dengan kode 1 merupakan responden yang melakukan

Tabel 3.

Motivasi ekstrinsik aitem $2(\mathrm{~N}=129)$

\begin{tabular}{lc}
\hline Saya hanya mau membeli BBM non-subsidi semata-mata & Persentase \\
karena lebih hemat dibandingkan BBM bersubsidi & $(\%)$ \\
\hline Sangat Tidak Setuju & 23.3 \\
Tidak Setuju & 30 \\
Netral & 35 \\
Setuju & 11.7 \\
Sangat Setuju & 0 \\
\hline Total (\%) & 60 \\
\hline
\end{tabular}

Tabel 4.

Hasil regresi logistik penggunaan produk inverter (AC dan/atau Kulkas) dan BBM Non-Subsidi ( $\mathrm{N}=129)$

\begin{tabular}{|c|c|c|c|c|c|c|c|c|}
\hline \multirow[t]{2}{*}{$\begin{array}{c}\text { Variabel } \\
\text { Determinan }\end{array}$} & \multicolumn{2}{|c|}{$\begin{array}{c}\text { Menggunakan } \\
\text { Inverter dan BBM } \\
\text { non-subsidi }\end{array}$} & \multicolumn{2}{|c|}{$\begin{array}{c}\text { Tidak Menggu- } \\
\text { nakan Inverter dan } \\
\text { BBM non-subsidi }\end{array}$} & \multirow[t]{2}{*}{ Nilai $\mathrm{p}$} & \multirow[t]{2}{*}{$\mathrm{aOR}$} & \multicolumn{2}{|c|}{$95 \% \mathrm{CI}$} \\
\hline & $\mathrm{n}$ & $\%$ & $\mathrm{n}$ & $\%$ & & & Lower & Upper \\
\hline NAT & & & & & $.019^{*}$ & 1.155 & 1.024 & 1.302 \\
\hline NEP & & & & & .200 & .938 & .850 & 1.035 \\
\hline Motivasi Intrinsik & & & & & $.043^{*}$ & 1.330 & 1.009 & 1.754 \\
\hline Motivasi Ekstrinsik & & & & & $.011^{*}$ & .608 & .414 & .892 \\
\hline Non-materialism & & & & & .305 & .854 & .632 & 1.154 \\
\hline \multicolumn{9}{|l|}{ Adanya handyman } \\
\hline Tidak Ada & 6 & 13.3 & 39 & 86.7 & & 1.000 & & \\
\hline Ada & 5 & 6.0 & 79 & 94.0 & .100 & .228 & .039 & 1.328 \\
\hline Constant & & & & & .169 & .000 & & \\
\hline
\end{tabular}


perilaku konservasi yang lebih beragam dan kompleks, karena melakukan perilaku konservasi di dua sektor sekaligus (rumah tangga dan transportasi). Analisis regresi logistik menggunakan listwise deletion, sehingga tidak menyertakan responden yang datanya missing dalam modelnya. Analisis ini mencakup 129 partisipan yang datanya lengkap dari total 143 partisipan yang terkumpul.

Hasil Omnibus Tests menunjukkan bahwa model fit, sehingga prediktor dapat menjelaskan variabel dependen dengan baik. Pseudo-R (Nagelkerke $\mathrm{R}^{2}$ ) menunjukkan nilai 0.543 , artinya $54.3 \%$ varian skor prediktor dapat menjelaskan varian skor variabel dependen. Prediktor yang teridentifikasi signifikan secara statistik adalah nilai pro-lingkungan (NAT) (1.155, 1.024-1.302, 0.019), motivasi intrinsik (1.330, 1.009-1.754, 0.043) dan motivasi ekstrinsik (0.608, 0.414-0.892, 0.011). Konsisten dengan temuan sebelumnya, responden dengan nilai pro-lingkungan (NAT) dan motivasi intrinsik yang intens akan lebih cenderung memilih menggunakan produk inverter dan membeli BBM non-subsidi, sedangkan individu yang mengedepankan keuntungan finansial akan lebih kecil peluangnya untuk memilih menggunakan produk inverter dan membeli BBM nonsubsidi. Tidak seperti data yang dicantumkan di Tabel 1, ada/tidaknya handyman ternyata tidak berkaitan dengan kemungkinan responden melakukan perilaku konservasi dengan ragam yang lebih kompleks.

\section{Diskusi}

Temuan penelitian ini mengkonfirmasi bahwa keputusan menggunakan produk inverter (AC dan/atau kulkas) dan BBM non-subsidi ternyata dipengaruhi oleh faktor determinan yang berbeda. Motivasi ekstrinsik dan ada/tidaknya handyman yang tinggal serumah dengan partisipan penelitian signifikan memengaruhi keputusan partisipan menggunakan satu atau lebih produk inverter. Responden dengan motivasi ekstrinsik yang lebih besar, akan cenderung menggunakan produk inverter, sedangkan responden yang tinggal serumah dengan seorang handyman menariknya justru cenderung kecil kemungkinannya memilih menggunakan produk inverter.

Motivasi ekstrinsik yang diartikan sebagai adanya keinginan untuk memperoleh keuntungan finansial merupakan determinan yang paling sering ditemui berkaitan dengan perilaku konservasi. Oleh karena itu, perilaku konservasi yang memerlukan biaya minimal, namun dengan keuntungan yang maksimal atau bahkan berkonsekuensi adanya insentif, akan lebih disukai dan mudah diadopsi oleh masyarakat (Young, 1990).

Menariknya, meski penelitian Young (1990) menyebutkan bahwa kehadiran handyman merupakan dimensi positional yang penting dalam menentukan perilaku konservasi, namun dalam penelitian ini, kehadiran handyman justru menurunkan peluang responden memilih menggunakan produk inverter. Menurut Young (1990), kehadiran seorang handyman dapat membantu mengurangi biaya perawatan dan pemasangan alat elektronik. Selain itu, handyman memiliki pengetahuan yang lebih mengenai fitur, spesifikasi dan utilisasi alat elektronik, sehingga ia mampu memilih produk yang lebih efisien. Namun dugaan penulis, dalam penelitian ini, evaluasi handyman masih berkutat pada pertimbangan keuntungan jangka pendek, karena harga produk inverter jauh lebih mahal dan membutuhkan biaya perawatan yang juga lebih mahal, meskipun secara jangka panjang, apabila mem- 
pertimbangkan biaya listrik yang terus naik setiap tahunnya, produk inverter jauh lebih ekonomis dari produk konvensional. Apalagi produk AC inverter biasanya menggunakan isian gas Freon yang lebih mahal daripada produk AC konvensional.

Temuan penelitian ini mendukung hasil penelitian sebelumnya, bahwa profil konsumen produk elektronik ramah lingkungan merupakan konsumen rasional, dimana penggunaan produk lebih didorong oleh motivasi egoistik, yakni mencapai keuntungan pribadi sebesarbesarnya (Dennis, Soderstrom, Koncinski, \& Cavanaugh, 1990; Turaga, Howarth, \& Borsuk, 2010; Young, 1990). Oleh karena itu, produsen produk inventer dan pemerintah mungkin dapat mempertimbangkan rational-economic model (REM) untuk mempromosikan produk elektronik ramah lingkungan (Dennis, et al., 1990). Kampanye model REM ini menekankan fungsi insentif sebagai faktor modifikasi perilaku. Produsen, misalnya dapat menggunakan strategi potongan harga (diskon) untuk harga produk, sedangkan pemerintah dapat mempertimbangkan pemotongan biaya listrik untuk rumah yang menggunakan produk inverter. Program ini pernah diterapkan di Amerika Serikat dan cukup sukses mengurangi impor minyak mentah sebesar 3.8 juta barel pada tahun 1990 (Dennis, et al., 1990). Namun program ini hanya efektif untuk mendorong perilaku konservasi individual, bukan pada level korporasi (Dennis, et al., 1990).

Lain halnya dengan responden yang menggunakan BBM non-subsidi. Penulis menyebut responden yang menggunakan BBM non-subsidi sebagai konsumen 'idealis' karena faktor determinan yang paling utama justru bukan motivasi eksternal seperti konsumen produk inverter, melainkan nilai pro-lingkungan (NAT).
Motivasi eksternal justru kontraproduktif dengan kemungkinan penggunaan BBM non-subsidi. Artinya, semakin tinggi keinginan individu untuk mencapai keuntungan finansial, maka ia akan kurang cenderung memilih menggunakan BBM non-subsidi.

Pada perilaku konservasi yang lebih kompleks (menggunakan produk inverter dan BBM non-subsidi sekaligus) juga ditentukan oleh nilai pro-lingkungan dan motivasi intrinsik. Temuan ini menguatkan penelitian-penelitian sebelumnya bahwa perilaku konservasi yang lebih kompleks hanya dilakukan oleh individu dengan selfdetermination dan kecenderungan altruisme yang tinggi (De Groot \& Steg, 2009; Turaga, et al., 2010). Individu ini melakukan perilaku konservasi karena didorong dengan adanya kebutuhan untuk mencapai citra diri positif, yakni sebagai individu yang memiliki tanggung jawab moral (Turaga et al., 2010). Oleh karena itu, pada konsumen produk ramah lingkungan yang "idealis" ini, pemerintah dan produsen perlu mengadopsi model kampanye berbasis nilai pro-lingkungan, di mana kampanye ini akan menonjolkan alasanalasan altruistik, sehingga konsumen akan merasa membeli produk ramah lingkungan adalah sesuatu yang layak dan benar untuk dilakukan. Misalnya, ketika mendorong masyarakat untuk membeli produk BBM non-subsidi, pemerintah dapat menonjolkan pesan bahwa dengan membeli produk BBM non-subsidi, maka masyarakat turut berpartisipasi untuk kemajuan pembangunan.

Sikap pro-lingkungan (NEP) ditemukan tidak signifikan memengaruhi perilaku konservasi, baik perilaku penggunaan produk inverter, maupun BBM nonsubsidi. Sikap pro-lingkungan, seperti yang diinvestigasi di penelitian sebelumnya, tidak serta merta dapat diterjemahkan 
menjadi perilaku, kecuali dikombinasikan dengan penawaran adanya keuntungan finansial atau keuntungan lainnya (Brandon \& Lewis, 1999). Selain itu, penelitian lainnya menunjukkan bahwa individu dengan sikap pro-lingkungan mungkin mengembangkan kepedulian terhadap kelestarian dan keberlanjutan (sustainability) lingkungan, namun mereka biasanya menganggap restorasi dan konservasi lingkungan merupakan tanggung jawab pemerintah dan korporasi besar, bukan tanggung jawab individual (Laroche, Bergeron, \& Barbaro-Forleo, 2001). Oleh karena itu, meskipun di beberapa penelitian, sikap pro-lingkungan merupakan prediktor yang penting dalam perilaku konservasi yang berinsentif dan mendatangkan keuntungan finansial (Brandon \& Lewis, 1999; Zhao, Gao, Wu, Wang, \& Zhu, 2014), namun gagal memprediksi perilaku konservasi yang membutuhkan investasi dan biaya tambahan (Laroche et al., 2001).

\section{Kesimpulan}

Kesimpulan yang dapat ditarik dari penelitian ini adalah faktor determinan yang paling utama dalam menjelaskan perilaku konservasi energi pada skala rumah tangga (dengan memilih produk inverter) adalah motivasi eksternal, sehingga menggunakan produk inverter merupakan pilihan rasional, karena dilandasi oleh alasan penghematan.

Sementara faktor determinan utama yang menjelaskan perilaku konservasi energi pada sektor transportasi (dengan menggunakan BBM non-subsidi) dan perilaku konservasi yang lebih kompleks adalah motivasi intrinsik dan nilai prolingkungan. Oleh karena itu, pemilihan produk BBM non-subsidi dan perilaku konservasi kombinasi (menggunakan produk inverter dan BBM non-subsidi) dianggap sebagai pilihan idealis karena dilandasi oleh nilai pro-lingkungan (NAT) dan motivasi intrinsik yang cenderung positif.

\section{Saran}

Penelitian selanjutnya memiliki peluang untuk menginvestigasi lebih jauh value dan belief yang punya andil penting dalam menjelaskan perilaku konservasi energi pada sektor transportasi. Lebih jauh lagi, akan sangat menarik apabila penelitian lanjutan berfokus pada pembuatan model perilaku yang dapat menjelaskan perilaku konservasi energi dalam sektor transportasi.

Selanjutnya, produsen produk inverter sebaiknya menonjolkan manfaat ekonomis yang mungkin diperoleh dengan menggunakan produk inverter untuk mempersuasi konsumen memilih produk inverter karena faktor motivasi eksternal cenderung lebih menonjol dalam memengaruhi pemilihan produk inverter.

\section{Kepustakaan}

APA Task Force. (2009). Psychology and global climate change: Addressing a multifaceted phenomenon and set of challenges. Washington DC: American Psychological Association.

Attari, S., DeKay, M., Davidson, C., \& de Bruin, W. (2010). Public perceptions of energy consumption and savings. Proceedings of the National Academy of Sciences of the United States of America, 107(37), 16054-16059. doi: 10.1073/ pnas. 1001509107/-/DCSupplemental. www.pnas.org/cgi/doi/10.1073/pnas.10 01509107

Brandon, G., \& Lewis, A. (1999). Reducing household energy consumption: A 
qualitative and quantitative field study. Journal of Environmental Psychology, 19, 75-85.

Bryman, A. (2012). Social research methods. Oxford: Oxford University Press.

Connor, S. (2014). IPCC report paints bleak picture of war, famine and pestilence: "Climate change is happening and no one in the world is immune." Diunduh tanggal 3 April 2014 dari http://www.independent.co.uk/enviro nment/climate-change/ipcc-reportpaints-bleak-picture-of-war-famineand-pestilence-climate-change-ishappening-andno-one-in-the-world-isimmune-9224777.html

Corbetta, P. (2003). Social research: Theory, methods and techniques. London: SAGE.

Corner, A., Venables, D., Spence, A., Poortinga, W., Demski, C., \& Pidgeon, N. (2011). Nuclear power, climate change and energy security : Exploring British public attitudes. Energy Policy, 39(9), 4823-4833. doi: 10.1016/ j.enpol. 2011.06.037

Costanzo, M., Archer, D., Aronson, E., \& Pettigrew, T. (1986). Energy conservation behavior: The difficult path from information to action. American Psychologist, 41(5), 521-528. doi: 10. 1037/0003-066X.41.5.521

De Groot, J. I. M., \& Steg, L. (2009). Morality and prosocial behavior: The role of awareness, responsibility, and norms in the norm activation model. The Journal of Social Psychology, 149(4), 42549. doi: 10.3200/SOCP.149.4.425-449

De Vaus, D. (2002). Surveys in social research 5th edition. London: Routledge.

Demeritt, D. (2006). Science studies, climate change and the prospects for constructivist critique. Economy and Society, 35(3), 453-479. doi: 10.1080/ 03085140600845024
Dennis, M. L., Soderstrom, E. J., Koncinski, W. S., \& Cavanaugh, B. (1990). Effective dissemination of energy-related information: Applying social psychology and evaluation research. American Psychologist, 45(10), 1109-1117. doi: 10.1037/0003-066X. 45. 10. 1109

Dunlap, R. E. (2008). The new environmental paradigm scale: From marginality to worldwide use. The Journal of Environmental Education, 40(1), 3-18. doi: 10.3200/JOEE.40.1.3-18

Dunlap, R. E., Liere, K. D. Van, Mertig, A. G., \& Jones, R. E. (2000). Measuring endorsement of the new ecological paradigm: A revised NEP scale. Journal of Social Issues, 56(3), 425-442.

Eysenbach, G., \& Wyatt, J. (2002). Using the internet for surveys and health research. J Med Internet Res, 4(2). doi: 10.2196/jmir.4.2.e13

Gifford, R. 1997. Environmental psychology: Principles and practice (2nd ed.). Boston: Allyn and Bacon.

Han, H. (2014). The norm activation model and theory-broadening: Individuals' decision-making on environmentallyresponsible convention attendance. Journal of Environmental Psychology, 40(2014), 462-471. doi: 10.1016/ j.jenvp. 2014.10.006

Harland, P., Staats, H., \& Wilke, H. A. M. (2007). Situational and personality factors as direct or personal norm mediated predictors of proenvironmental behavior: Questions derived from norm-activation theory. Basic and Applied Social Psychology, 29(4), 323-334. doi: $10.1080 / 019735$ 30701665058

Kaiser, F., Wölfing, S., \& Fuhrer, U. (1996). Environmental attitude and ecological behaviour. Journal of Environmental Psychology, 19(1), 1-19. doi: 10.1006/ 
jevp.1998.0107

Kantola, S. J., Syme, G. J., \& Campbell, N. A. (1984). Cognitive dissonance and energy conservation. Journal of Applied Psychology, 69(3), 416-421. doi: 10. 1037/0021-9010.69.3.416

Laroche, M., Bergeron, J., \& Barbaro-Forleo, G. (2001). Targeting consumers who are willing to pay more for environmentally friendly products. Journal of Consumer Marketing, 18(6), 503-520. doi: 10.1108/EUM000000000 6155

Mayer, A. (2014). Climate change: 4 countries that are fighting the trend. Diunduh tanggal 3 April 2014 dari http://www.cbc.ca/news/technology/cl imate-change-4-countries-that-arefighting-the-trend-1.2593219

Muryanto, B. (2014). Sustainable consumption needed for environmental health. Diakses tanggal 3 April 2014, dari http://www.thejakartapost.com /news/2014/04/01/sustainableconsumption-needed-a-health.html

Nossar, R. (2014). Di ASEAN, Indonesia paling boros listrik $A C$. Diakses pada tanggal 29 April 2014, dari http://industri.kontan.co.id/news/diasean-indonesia-paling-boros-listrik-ac

Peattie, K. (2010). Green consumption: Behavior and norms. Annual Review of Environment and Resources, 35(1), 195228. doi: 10.1146/annurev-environ032609-094328

Pusat Teknologi Pengembangan Sumber Daya Energi. (2014). Outlook energi Indonesia 2013. Diunduh dari www.bppt.go.id

Raaij, W. Van, \& Verhallen, T. (1983). A behavioral model of residential energy use. Journal of Economic Psychology, 3, 39-63. doi: 10.1016/01674870(83)900570
Schultz, P. W. (2005). Values and their relationship to environmental concern and conservation behavior. Journal of Cross-Cultural Psychology, 36(4), 457475. doi: $10.1177 / 0022022105275962$

Schultz, P. W., \& Zelezny, L. (1999). Values as predictors of environmental attitudes: Evidence for consistency across 14 countries. Journal of Environmental Psychology, 19, 255-265. doi: 10.1006/jevp.1999.0129

Sekretariat Panitia Teknis Sumber Energi. (2006). Blueprint pengelolaan energi nasional 2006-2025. Diunduh dari www.esdm.go.id.

Steg, L., \& de Groot, J. (2010). Explaining prosocial intentions: Testing causal relationships in the norm activation model. The British Journal of Social Psychology/The British Psychological Society, 49(Pt 4), 725-43. doi: 10.1348/ 014466609X477745

Steg, L., Van den Berg, A. E., \& De Groot, J. I. (2013). Environmental psychology: An introduction. Chicester: BPS Blackwell.

Stern, P. (1992). What psychology knows about energy conservation. American Psychologist, 47(10), 1224-1232. doi: 10. 1037//0003-066X.47.10.1224

Stratospheric Protection Division. (2014). What you should know about refrigerants when purchasing or repairing a residential A/C system or heat pump. Diunduh pada 29 April $29 \quad 2014$ dari http://www.epa.gov/ozone/title6/phaseout/22phaseout.html

Sue, V. M., \& Ritter, L. A. (2006). Conducting online surveys. Quality and quantity. London: SAGE.

Sugiyono, A. (2012). Data historis konsumsi energi dan proyeksi permintaanpenyediaan energi di sektor transportasi. In Adiarso (Ed.), Prosiding Seminar dan Peluncuran Buku Outlook 
Energi Indonesia 2012 (pp. 24-29). Jakarta: Badan Pengkajian dan Penerapan Teknologi.

Turaga, R. M. R., Howarth, R. B., \& Borsuk, M. E. (2010). Pro-environmental behavior: Rational choice meets moral motivation. Annuals of the New York Academy of Sciences, 1185, 211-24. doi: 10.1111/j.1749-6632. 2009.05163.x

van der Werff, E., \& Steg, L. (2015). One model to predict them all: Predicting energy behaviours with the norm activation model. Energy Research $\mathcal{E}$ Social Science, 6, 8-14. doi: 10.1016/ j.erss.2014.11.002

Vining, J., \& Ebreo, A. (2002). Emerging theoretical and methodological perspectives on conservation behaviour. Urbana, 60607(312), 541-558.

Young, R. De. (1985). Encouraging environmentally appropriate behavior: The role of intrinsic motivation. Journal of Environmental Systems, 15(4), 281292.

Young, R. De. (1990). Some psychological aspects of living lightly: Desired lifestyle patterns and conservation behavior. Journal of Environmental Systems, 203(3), 215-227.

Young, R. De. (1996). Some psychological aspects of reduced consumption behavior the role of intrinsic satisfaction and competence motivation. Environment and Behavior, 28(3), 358-409.

Zhao, H. H., Gao, Q., Wu, Y. P., Wang, Y., \& Zhu, X. D. (2014). What affects green consumer behavior in China? A case study from Qingdao. Journal of Cleaner Production, 63, 143-151. doi: 10.1016/ j.jclepro.2013.05.021 